\title{
Avcı Bakteriler
}

\author{
Mustafa Önol, Hakan Yardımcı \\ Ankara Üniversitesi Veteriner Fakültesi Mikrobiyoloji Anabilim Dalı, Ankara
}

Geliş Tarihi / Received: 21.02.2018, Kabul Tarihi / Accepted: 30.05.2018

\begin{abstract}
Özet: Avcılık canlılığın her ölçeğinde görülebilen bir etkileşim biçimidir. Bakteriyofajların da dahil edilmesi durumunda; mikronlar ile ölçülen canlılardan metreler ile ölçülen hayvanlara kadar uzanan bir avcı skalası oluşur. Ökaryot ve prokaryot canlıların gösterdiği avcılık modelleri arasında yatan temel fark, prokaryot hücrelerin avlarını yutamamasından kaynaklanır. Avcı bakteriler ilk kez 1962 yılında Heinz Stolp tarafından; küçük, yüksek motiliteye sahip, zorunlu avc1, Gram negatif bakteriler olarak tanımlanmıştır. Bu bakteriler, hücreye tutunma ve hücreyi lize etme yeteneğine sahiptir. Doğada yaygın olarak bulunan avcı bakterilerin etki mekanizmaları tam olarak keşfedilememiş ve bu bakterilerin tamamı filogenetik olarak sınıflandırılamamıştır. İn-vivo ve in-vitro ortamlarda yapılan çalışmalarda avcı bakterilerin geniş bir bakteri skalasına etki gösterdiği bulunmuştur. Bu derlemede avcı bakterilerin filogenetik olarak sınıflandırılması, temel özellikleri ve etki mekanizmaları ile avcı bakteriler kullanılarak yapılan bazı çalışmalar anlatılmıştır.
\end{abstract}

Anahtar kelimeler: Avcı bakteriler, Bdellovibrio ve benzeri organizmalar

\section{Predator Bacteria}

\begin{abstract}
Predatory is a form of interaction that can be seen at every scale of life. When viruses are considered, there are predators creatures on every scale. The main difference between eukaryotic and prokaryote predators is that prokaryotes are not capable of swallowing. Predator bacteria were first discovered by Heinz Stolp in 1962; small, high motility, obligatory predator, Gram negative bacteria. The very small, very fast mobility of bacteria identified by Heinz Stolp has the ability to attach to cells and lyse cells. The mechanisms of action of the predominantly hunting bacteria in the land have not been fully explored, and not all of these bacteria have been classified phylogenetically. Studies done in-vivo and in-vitro have shown that predator bacteria act on a large group of bacteria. In this review phylogenetic classification of predator bacteria, basic features, mechanism of action and current studies using predator bacteria are explained.
\end{abstract}

Key words: Predator bacteria, Bdellovibrio and like organisms

\section{Giriş}

Avcı bakteriler ilk kez 1962 yılında Heinz Stolp tarafından; küçük, yüksek motiliteye sahip (yaklaşık olarak saniyede 100 vücut boyu), zorunlu avcı, Gram negatif bakteriler olarak tanımlanmıştır. Bu bakteriler, hücreye tutunma ve hücreyi lize etme yeteneğine sahiptir. Bu özellikleri nedeniyle bu bakteriler morfolojilerine ve yaşam şekillerine uygun olarak Bdellovibrio bacteriovorus olarak tanımlanmıştır. "Bdella" kelimesi Yunanca kan emici anlamina gelmektedir. Bu terim ilk kez taksonomist Profesör Robert E. Buchanan tarafindan kullanılmıştır. Bdellovibrio ve benzeri organizmalar (BALO's) olarak tarif edilen zorunlu avciların farklı aileler oluşturduğu yakın zamana kadar bilinmediği için BALO'lar $\delta$-proteobakteriler içerisinde tanımlanmakta idi. Yapılan son çalışmalar ise zorunlu avciların farklı proteobakteriyel sinıflarda bulunabileceğini göstermiştir. Ancak bazı bakteriler farklı ailelerden gelseler bile eylem şekilleri, morfolojileri ve davranış biçimleri olarak BALO'lar ile benzer oldukları için BALO terimi tüm avcı bakterileri kapsayan bir terim halini almıştır (Örneğin $M i-$ cavibrio spp. $\alpha$-proteobakteriler sinıfina aittir) [7]. Avcı bakteriler taksonomik olarak farklı gruplarda bulunmalarına karşın çok az sayıda avcı bakteri türü bilinmektedir. Bir bakterinin avcı olup olmadığını anlamamızı sağlayacak herhangi bir genetik imza taşımaması, avcı bakterilerin bulunmasını zorlaştırmaktadir [10].

\section{Avcı Bakterilere Genel Bakış}

Avcılık canlılığın her ölçeğinde görülebilen bir etkileşim biçimidir. Bakteriyofajların da dahil edilmesi durumunda; mikronlar ile ölçülen canlılardan metreler ile ölçülen hayvanlara kadar uzanan bir avc1 
skalas1 oluşur. Bu ölçeğin en düşük basamağ1 olan virüsler ve bakteriler düşünüldüğünde genellikle avcılar avlarından daha küçük boyutlara sahiptir. Ancak ölçeğin üst basamaklarında bu durumun tam tersi görülmektedir. Av ve avcı arasındaki boyut değişiminin tersine döndüğü nokta olarak prokaryot ve ökaryot hücrelerin birbirinden ayrılması kabul edilebilir. Çünkü protozoonlar genellikle avlarından (bakterilerden) daha büyüktür. Ökaryot ve prokaryot canlıların gösterdiği avcılık modelleri arasında yatan temel fark, prokaryot hücrelerin avlarını yutamamasından kaynaklanır. Ancak fagositoz özelliği olmayan bir hücre kendisinden daha büyük bir hücreyi avlayamaz demek doğru değildir. Küçük boyutlara sahip zorunlu avcı bir hücrenin kendisinden daha büyük bir hücreyi avlaması farklı avantajlar sağlayabilir. Bu avantajlara; büyümesi ve çoğalmas1 için gerekli olan tüm maddeleri tek seferde elde edebilmesi örnek gösterilebilir [4]. Daha büyük bir av, başarılı bir avcıya bol miktarda besin ve enerji kaynağı sağlar. Ayrıca daha küçük bir avcı ava çok daha kolay yerleşebilir [7].

\section{Avcı Bakterilerin Filogenetik Olarak Sınıflandırılması ve Etki Mekanizmaları}

\section{Proteobacteria}

\section{Ensifer adhaerens}

Bakteri ilk kez Ensifer adhaerens ismi ile 1982 y1lında litaretüre girmiş, 1988 yılında ismi Sinorhizobium adhaerens olarak değiştirilmiş ve yapılan çalışmalar sonucunda 1990 yılında tekrar eski ismini almıştır [7]. Toprakta bulunan Ensifer adhaerens'in Gram pozitif ve Gram negatif bakterilerden oluşan geniş bir av spekturumu bulunmaktadır. Ancak Ensifer adhaerens zorunlu avcı bir bakteri değildir [3]. Ensifer adhaerens avı ile arasında sitoplazmik bir köprü kurarak avına bağlanır. Bu bağlanma "çit" benzeri bir bağlanmadır. Bir hücreye aynı anda birçok avcı hücre bağlanabilir. Bağlanma sonucunda av lize edilir [7]. Ayrica bakteriden elde edilen allisinase enzimi ile elde edilen allisinin fungisit etkisi gösterilmiştir [17].

\section{Micavibrio spp.}

Micavibrio'lar Gram negatif çomak şeklinde bakterilerdir. Zorunlu avcı yaşam döngüsüne sahiptirler. $\mathrm{Bu}$ yaşam döngüsünün hareketli bakte- rinin ava ihtiyaç duyduğu saldırı dönemi ve avına geri dönüşümsüz olarak bağlandığı bağlanma döneminden oluştuğu düşünülmektedir. Bu bakteriler avlarına yüksek derecede spesifiktir [7]. M. admirantus ve $M$. aeruginosavorus olmak üzere iki türü tanımlanmıştır. Stenotrophomonas maltophila'yı av olarak kullanılarak M. admirantus, Pseudomonas aeruginosa, Burkholderia cepacia ve Klebsiella pneumoniae kullanılarak ise M. aeruginosavorus izole edilmiştir [8]. Micavibrio türlerini üretebilmek için av olarak 55 farklı tür denenmiş ancak başarı11 olunamamıștır. Ayrica ne kadar zengin besi yeri kullanılsa da konak bağımsız Micavibrio'lar üretilememiştir [7]. Micavibrio'lar epibiotik avcılardır ve avlarının periplasmik membranına nüfuz etmezler. Avlarının hücre duvarına yapışarak kendilerini beslerler. Bu süreçte çoğalır ve avladıkları hücrenin ölümüne neden olurlar. Bu durum parazitik bir yaşam döngüsüne sahip olmaları anlamı taşır [15].

\section{Cupriavidus necator}

Gram negatif, kısa, çomak şekilli bakterilerdir. Zorunlu avcı olmayan bu bakteriler topraktan izole edilmiştir. Zorunlu avcı olmamalarına rağmen Agromyces ramosus, Arthrobacter globiformis, Azotobacter vinelandii, Bacillus subtilis, Bacillus thurigiensis, Ensifer adhaerens, Escherichia coli, Micrococcus luteus, Staphylococcus aureus ve Streptomyces spp. gibi geniş bir Gram negatif bakteri grubunu avladığı gözlemlenmiştir [7].

\section{Aristabacter necator}

Gram negatif bir bakteridir. Avına gruplar halinde saldıran ve çit benzeri tutunma gösteren Aristabacter necator zorunlu bir avc1 değildir. Aristabacter necator' un bu yüksek inhibisyon gücü ürettiği güçlü kimyasal maddelerle ve bu kimyasalların sinerjistik çalışmaları ile ilişkilidir. İn-situ incelemelerde bakterinin topraktaki yarışmacı ortamda hayatta kalma becerisinin çok yüksek olduğu ve diğer mikroorganizmaları ortadan kaldırdığı gözlenmiştir. Aristabacter necator gibi avcı bakteriler, farklı biyokimyasal maddelerin potansiyel bir kaynağ 1 olabilirler.

\section{Stenotrophomonas maltophilia}

Stenotrophomonas maltophilia Gram negatif, hareketli, oldukça küçük boyutlara sahip (0.7-1.8 × 0.4 $0.7 \mu \mathrm{m})$, aerobik, katalaz ve oksidaz pozitif, nonfer- 
mantatif bir bakteridir [6]. Bakterinin av ile direkt teması henüz gözlemlenmemiş olsa da etkenin bulunduğu ortamlarda hayalet hücrelerin görülmesi ve etkenin hasarlı hücrelerden yay1lan sinyalleri takip etmesi onun zorunlu olmayan bir avc1 sayılması için yeterli görülmüştür [7]. Stentrophomonas'ın günümüzde bilinen 8 türü genel olarak toprakta ve bitkilerle yakın ilişkili olarak yaşamaktadır. Doğal ve yapay kirleticileri parçalama ve değerli biyomoleküller üretme özelliklerine sahip olmaları nedeniyle bitkilerin gelişimi açısından oldukça değerlidirler. Ancak özellikle Stenotrophomonas maltophilia insanlarda patojenik etki gösterdiği ve yüksek antibiyotik dirençliliğine sahip olduğu için dezavantajları göz ardı edilmemelidir [18].

\section{Lysobacter spp.}

Gram negatif olan bu bakteriler çok uzun hücreler ve flamentler şeklindedir (yaklaşık $70 \mu$ kadar). $L y$ sobacter'ler çok miktarda salg1 üretir. Bu sayede katı ortamlarda kolonileri kayma hareketi gerçekleştirebilir. Lysobacter türlerini, besi yerinde üretebilmek için besi yerine bakteri eklenmesi (örneğin; Arthrobacter) gerekmektedir [12]. Lysobacter'ler, kurt sürüsü taktiği kullanarak avlarına saldırmaktadır. Bu taktiği kullanmalarının nedeni olarak avın hücre duvarına bıraktıkları lize edici enzimlerin yoğunluğunu korumak istemeleri gösterilebilir [5]. $L y$ sobacter'ler enzimlerini biraktıktan sonra enzimlerden etkilenecek ilk yapı olan peptidoglikan tabakasında hızlı bir lizis başlamaktadır [12]. Bu enzimler pozitif yüklüdür ve birçok Gram pozitif bakterinin peptidoglikan tabakasına etki gösterirken sadece birkaç Gram negatif bakteriyi etkileyebilmektedir.

\section{Myxobacteria spp.}

Myxobacteria'ların en karakteristik özelliği sürüler oluşturmaları ve çok hücreli yaşam tarzına sahip olmalarıdır. Örneğin, vejatatif Myxobacteria hücreleri kordine bir şekilde hareket ederek sürüler halinde avlanırlar, bir başka deyişle sosyal bakterilerdir [9]. Oldukça kuvvetli şekilde kayma hareketi yapabilen Myxobacteria'lar bu özellikleri sayesinde özellikle toprakta etkili bir şekilde avlanabilmektedir. Avlanma, ortamda bulunan tüm av hücreleri lize edilene kadar devam etmektedir [11]. Ayrica ortamda bulunan besin miktarı azaldığında Myxobacteria hücreleri henüz mekanizması bilinmeyen ancak ke- motaksis yolu ile olduğu düşünülen bir yöntemle haberleşerek sporokarp meydana getirmektedir. $\mathrm{Bu}$ sporokarplar Myxobacteria türlerine göre renk ve boyut olarak farkl111klar göstermektedir.

\section{Bdellovibrio ve benzeri organizmalar}

Delta proteobacteria sinifinda bulunan Bdellovibrio spp., Bacteriovorax spp., ve Peridibacter spp. Bdellovibrio ve benzeri organizmalar ad1 altında kümelenmiştir (d-BALO's). Bdellovibrio ve benzeri organizmalar ilk olarak 1962 y1lında Heinz Stolp tarafindan toprakta yaşayan bakteriyofajların izolasyonu sirasında bulunmuştur ve bulunduğu günden itibaren hakkında en çok çalışma yapılan avcı bakteri grubu olmuştur [7]. d-BALO'lar Gram negatif, küçük $(0.25-0.5 \times 0.75-2 \mu \mathrm{m})$, çomak şeklinde, yüksek motiliteye sahip bakterilerdir. Tek k1lıfl, polar bir flagelluma sahiptirler. Flagellum klasik bir dalga hareketi gösterir. d-BALO'lar diğer Gram negatif bakterilerin zorunlu avcılarıdır, diğer bir deyişle çoğalmak için tamamen diğer bakterilere bağımlıdırlar. Bu bakterilerin yaşam döngüleri; periplasmik yaşam evresi, av arama evresi, bağlanma veya tutunma, invazyon evresi, bdelloblast evresi, büyüme evresi, çoğalma ve konakçıyı parçalama evresi şeklindedir. Tutunma evresinde bakteri hücresi seçici değildir, bu nedenle Gram pozitif bakterilere veya ortamda bulunan başka büyük moleküllere tutunma gerçekleşebilir. Ancak bu tutunma kalıcı değildir. Ortam sicaklığ 1 ve pH'in tutunma üzerine etkisi bulunmaktadır. $\mathrm{Bu}$ faktörler rastgele tutunma oranını düşürmektedir. Avcı hücre uygun bir hücreyle temas sağladıktan sonra geri dönüşü olmayan kalıcı tutunma gerçekleşir. Bu dönemde av olan hücrenin hücre duvar1 yapısının önemli olduğu düşünülmektedir. Avcı hücre tutunma gerçekleştiğinde fimbria benzeri avcı uzantılar ile hücre duvarını deler. Hücre içine nüfuz eden bakteri flagellasını dış ortamda birakır. Bu durumdaki hücreye bdelloblast ismi verilmektedir [7]. Avcı hücre periplasmik membranda iken hidrolitik enzimler salgilamaya devam eder ve konakçıya ait makro molekülleri parçalar. İntra periplazmik membrana yerleşen BALO filamentöz bir yap1 oluşturur ve DNA replikasyonunu başlatır. Konak hücrenin tüm kaynakları tüketildiğinde büyük filamentöz hücre 2 ila 9 yavru hücreye bölünür [4]. Bölünme gerçekleştikten sonra yavru hücreler flagellarını oluşturur ve konak hücreyi parçalayarak lize ederler [7]. 


\section{Chloroflexi}

Chloroflexi genusu içerisinde bulunan Herpetosiphon türleri, Gram negatif olan, ancak tipik bir Gram negatif hücre duvarına sahip olmayan aerobik, kemo-organotrofik, filamentöz bakterilerdir [12]. Ölü hücreleri olduğu kadar canlı hücreleri lize etme yeteneğine sahip bu bakterilerin Gram negatif bakteriler ve sporsuz Gram pozitif bakterileri avlayabildikleri tespit edilmiştir. Laboratuvar ortamında yapılan çalışmalarda avlayacakları bakteri kolonilerine filamentleri yardımıyla fiziksel basınç uyguladıkları, koloniyle temas ettikleri noktadan koloni merkezine kadar bakteri hücrelerini lize ederek devam ettikleri gözlemlenmiştir. Bu strateji de kurt sürüsü taktiğine benzetilmiştir [7].

\section{Actinobacteria}

\section{Streptoverticillium}

Streptoverticillium Gram pozitif, flamentli, fakültatif avc1 bakteridir. Ensifer adhaerens ile birlikte topraktan izole edilmiştir. Micrococcus luteus kolonilerini iyi bir şekilde lize ederek avladığ gözlemlenmiştir [3].

\section{Agromyces ramosus}

Actinobacteria takımında bulunan bu bakteri topraktan izole edilmiştir. Fakültatif bir avcıdır. Azotobacter vinelandii, Rhizobium leguminosarum, Sinorhizobium meliloti, Agrobacterium tumefaciens gibi Gram negatif ve Gram pozitif bakterilerin yanı sıra maya hücrelerini kemotaksis içeren bir yol ile avladığı gözlemlenmiştir. Avını öldürebilmek için av hücresine çok yakın olması veya temas etmesi gerekmektedir. Agromyces ramosus toprakta bulunan bakterileri avladığ gibi kendisi de Cupriavidus necatora av olabilmektedir [7].

\section{Filogenetik Olarak Sinıflandırılamayan Avcı Bakteriler}

\section{Vampirococcus ve Daptobacter}

$\mathrm{Bu}$ bakterilerden birisi olan Vampirococcus, oval veya nispeten çomak şeklinde bakterilerdir. Küçük boyutlara sahip $(0.3 \times 0.6 \mu \mathrm{m})$ bu bakterilerin hareket etme yetenekleri yoktur. Bu nedenle kemotaksis yapamazlar. Zorunlu avcı olan Vampirococcus'lar epibiotik avcılardır ve av hücrelerinin duvarlarına bağlanırlar [7]. Daptobacter'ler Gram negatif, ço- mak şeklinde, $0.5 \times 1.5 \mu \mathrm{m}$ boyutlarında, hareketli ve fakültatif anaerob bakterilerdir. İn vitro koşullarda zengin besi yerlerinde çoğalması sağlanan Daptobacter'ler fakültatif avcılardır. Bu bakteriler avlarına elektron opak yapılarla bağlandıktan sonra hücre membranını parçalayarak sitoplazmasını tüketir, avladıkları hücrelerin içinde çoğalabilmektedirler. $\mathrm{Bu}$ avlanma yöntemine, doğrudan istila stratejisi adı verilmiştir [7].

\section{Aveı Bakteriler ile Yapılan Bazı Çalışmalar}

Bdellovibrio bacteriovorus başta olmak üzere avc1 bakteriler, zoonotik patojenler olan Escherichia coli ve Salmonella'nın da dahil olduğu veteriner hekimliğinde önem taşıan Gram negatif bakteriler ile avlanan bir bakteridir. Bdellovibrio'lar biyolojik kontrol ajanı olarak iyi bir potansiyele sahiptirler ancak canlı hayvanlar üzerinde çok az sayıda deneme yapılmıştır [1].

Önemli bir insan patojeni olan Shigella ile infekte olan zebra balığı yavruları (Danio rerio) üzerine olan etkisinin araştırıldığ 1 bir çalışmada; Bdellovibrio bacteriovorus balıklara injekte edilmiş ve in-vivo ortamda Shigella karşısında etki göstermiştir [16].

Tavuklar üzerinde yapılan bir çalışmada avcı bakterilerin tavuk vücut sıcaklığında zorlanmalarına karşın yaşayabildikleri gösterilmiştir. Buna ek olarak aynı çalışmada sağlıklı S. Enteritidis ile infekte hayvanlar üzerinde Bdellovibrio bacteriovorus oral çözeltiler yolu ile kullanılarak test edilmiştir. Çalışmanın sonuçlarına göre infekte hayvanların gastrointestinal sisteminde olumlu bir iyileşme tespit edilmiş ve avcı bakterilerin, tavukların sağlığına herhangi bir olumsuz etki göstermedikleri belirlenmiştir [1].

$\mathrm{Bu}$ bakterilerin toksik etkileri araştırıldığında; Bdellovibrio bacteriovorus ve Micavibrio aeruginosavourus'un insan korneası için toksik olmadığ 1 bulunmuştur. Bakteriler insanlarda, IL-8 üretimini uyarmış ancak IL-1 $\beta$ düzeyinde herhangi bir değişime neden olmamıştır. Benzer deney tavşanlar üzerinde uygulanmıştır. Beş gruba ayrılan tavşanların gözlerine günde 5 doz olmak üzere 5 gün boyunca fizyolojik tuzlu su, vancomycin, Micavibrio aeruginosavorus, Bdellovibrio bacteriovorus HD100 ve Bdellovibrio bacteriovorus 109J solüsyonları damlatılarak gözlenmiştir. Çalışma sonuçlarında bu 
bakteri suşları tavşanların oküler dokusunda bir infilamasyona neden olmadığı gibi herhangi bir toksik etki yaratmamıştır [13].

İnfeksiyoz sığır keratokonjunktiviti dünya genelinde ciddi ekonomik ayıplara neden olan, sığırların ciddi ve bulaşıcı bir göz hastalığı olduğu bilinmektedir. Bdellovibrio bacteriovorus 109J suşunun sığır keratokonjunktivitinin etkeni olan Moraxella bovis üzerine olan etkisi araştırılmış; yapılan in-vivo çalışmalarda Bdellovibrio bacteriovorus 109J suşunun memeli hücreleri üzerine herhangi bir toksik etkisi olmadığı gibi Moraxella bovis infeksiyonlarının tedavisinde kullanılabilecek potansiyel bir ajan olduğu belirtilmiştir [2].

Bdellovibrio bacteriovorus 109J suşunun Bdellovibrio bacteriovorus ve Micavibrio aeruginosavorus kullanılarak yapılan fare deneylerinde hem sağlıklı hem de Klebsiella pneumoniae ile infekte edilen fareler kullanılmıștır. Nazal yol ile avcı bakterilere maruz birakılan sağliklı farelerin 48 saat boyunca immunoglobulin değerleri ELISA yöntemi kullanılarak ölçülmüş ve önemli bir artışa rastlanmamıştır. Sağlıklı farelerde herhangi bir akciğer problemi oluşmadığg gibi deneyin 10. gününde avc1 bakteriler vücuttan tamamen temizlenmiştir. İnfekte edilen hayvanlara aynı şekilde nazal yol ile avcı bakteriler verilmiş, sonuç olarak patojen yükünün kayda değer bir ölçüde azaldığ 1 tespit edilmiştir [14].

\section{Kaynakça}

1. Atterbury RJ, Hobley L, Till R, Lambert C, Capeness MJ, Lerner TR, Sockett RE, (2011). Effects of orally administered Bdellovibrio bacteriovorus on the well-being and Salmonella colonization of young chicks. Appl Environ Microbiol. 77(16), 5794-5803.

2. Boileau, M. J., Clinkenbeard, K. D., \& Iandolo, J. J. (2011). Assessment of Bdellovibrio bacteriovorus 109J killing of Moraxella bovis in an in vitro model of infectious bovine keratoconjunctivitis. Canadian Journal of Veterinary Research. 75(4), 285-291.

3. Casida LE Jr (1980). Bacterial predators of Micrococcus luteus in soil. Appl Environ Microbiol. 39, 1035-1041.

4. Chanyi R.M (2014). Cell Biology of the Entry of Bdellovibrio and Like Organisms. Graduate Program in Microbiology and Immunology, The University of Western Ontario, PhD Thesis, Canada.
5. Dworkin M (1999). Fibrils as extracellular appendages of bacteria: Their role in contactmediated cell-cell interactions in Myxococcus xanthus. Bioessays. 21, 590-595.

6. Gilligan PH, Lum G, VanDamme PAR, Whittier S (2003). Burkholderia, Stenotrophomonas, Ralstonia, Brevundimonas, Comamonas, Delftia, Pandoraea, and Acidivorax. eds. Murray PR, Baron EJ, Jorgensen JH, et al. In: Manual of Clinical Microbiology Eighth edition. ASM Press, Washington, DC. p.729-748

7. Jurkevitch E (2007). A brief history of short bacteria: A chronicle of Bdellovibrio (and like organisms) research. eds. Jurkevitch, E. In Predatory Prokaryotes-Biology, Ecology and Evolution. Springer, Verlag Heidelberg, Germany p. $20-40$

8. Lambina VA, Afinogenova AV, Romai Penabad S, Konovalona SM, Pushkareva AP (1982). Micavibrio admirandus gen. et sp. nov. Mikrobiologiya. 51, 114-117.

9. Muñoz-Dorado J, Marcos-Torres FJ, García-Bravo E, Moraleda-Muñoz A, Pérez J (2016). Myxobacteria: Moving, killing, feeding, and surviving together. Frontiers in Microbiology. 7, 781 .

10. Pasternak Z, Ben Sasson T, Cohen Y, Segev E, Jurkevitch E (2015). A new comparative-genomics approach for defining phenotype-specific indicators reveals specific genetic markers in predatory bacteria. PLoS ONE. 10(11), e0142933.

11. Reichenbach H, Gerth K, Irschik H, Kunze B, Hofle G (1988). Myxobacteria: A source of new antibiotics. Trends Biotechnol. 6, 115-121.

12. Reichenbach H (2001). The genus Lysobacter. Eds: Dworkin M et al, In: The Prokaryotes: An Evolving Electronic Resource for the Microbiological Community. Springer, Berlin Heidelberg, Germany.

13. Romanowski EG, Stella NA, Brothers KM, Yates KA, Funderburgh ML, Funderburgh JL, ... Shanks RMQ (2016). Predatory bacteria are nontoxic to the rabbit ocular surface. Scientific Reports. 6, 30987.

14. Shatzkes K, Singleton E, Tang C, Zuena M, Shukla S, Gupta S, Kadouri DE (2016). Predatory bacteria attenuate Klebsiella pneumoniae burden in rat lungs. mBio. 7(6), e01847-16.

15. Wang Z, Kadouri DE, Wu M (2011). Genomic insights into an obligate epibiotic bacterial predator: Micavibrio aeruginosavorus ARL 13. BMC Genomics. 12, 453.

16. Willis, A. R., Moore, C., Mazon-Moya, M., Krokowski, S., Lambert, C., Till, R., ... Sockett, R. E. (2016). Injections of Predatory Bacteria Work Alongside Host Immune Cells to Treat Shigella Infection in Zebrafish Larvae. Current Biology. 26(24), 3343-3351.

17. Yutani M, Taniguchi H, Borjihan H, Ogita A, Fujita K, Tana$\mathrm{ka} \mathrm{T}$ (2011). Alliinase from Ensifer adhaerens and its use for generation of fungicidal activity. AMB Express. 1, 2.

18. Zer Y, Karaoğlan İ, Çevik S, Erdem M (2009). Stenotrophomonas maltophilia suşlarının antibiyotik duyarlılıklarının irdelenmesi. Gaziantep Üniversitesi Klinik Dergisi. 22, 21-24. 